\title{
Variability in eosinophilic infiltration within the rectal mucosa of clinically healthy horses
}

\author{
M. M. Sloet van Oldruitenborgh-Oosterbaan' and G. C. M. Grinwis ${ }^{2}$ \\ 1 Department of Equine Sciences, Faculty of Veterinary Medicine, Utrecht University, Utrecht, The Netherlands \\ 2 Department of Pathobiology, Faculty of Veterinary Medicine, Utrecht University, Utrecht, The Netherlands
}

\begin{abstract}
Summary: Rectal biopsies are often utilized as a possible aid to the diagnosis of inflammatory bowel disease. The present study focussed on the results of rectal biopsies as a diagnostic technique in healthy horses. The number of eosinophils in the lamina propria and the submucosa was counted in as many crypt areas as possible in histology slides of rectal biopsies collected from healthy mature warmblood horses, The results were expressed as number of eosinophils per crypt area. There proved to be wide inter-individual and intra-individual variations in the number of eosinophils and this makes the use and relevance of a rectal biopsy questionable.
\end{abstract}

Keywords: horse, rectal biopsy, eosinophilic infiltration, inflammatory bowel disease, histology

Citation: Sloet van Oldruitenborgh-Oosterbaan M. M., Grinwis G. C. M. (2017) Variability in eosinophilic infiltration within the rectal mucosa of clinically healthy horses. Pferdeheilkunde, 135-138; DOI 10.21836/PEM20170104

Correspondence: Prof. M. M. Sloet van Oldruitenborgh-Oosterbaan, Department of Equine Sciences, Faculty of Veterinary Medicine, Utrecht University, Yalelaan 1 14, 3584 CM, Utrecht, The Netherlands; Email: m.sloet@uu.nl

\section{Introduction}

Inflammatory bowel disease is a complex syndrome and multisystemic eosinophilic epitheliotropic disease (MEED) and idiopathic eosinophilic enterocolitis are part of this complex. Histopathological examination of rectal biopsies has been widely used as an aid to the diagnosis of intestinal disease with variable success (Lindberg et al. 1996, Mair et al. 2006, Ricketts 1996, Schumacher et al. 2000). In cases of eosinophilic gastroenteritis, microscopic lesions with diffuse eosinophilic infiltration of the lamina propria and submucosa are often more widespread than gross lesions (Pass and Bolton 1982). However, eosinophils are commonly identified within the rectal mucosa and submucosa without any overt digestive tract clinical symptoms, and their presence in rectal biopsies is not necessarily proof of either multisystemic eosinophilic epitheliotropic disease (MEED) or idiopathic eosinophilic enterocolitis (Mair et al. 2006).

The extent of eosinophilic infiltration observed before a diagnosis of eosinophilic enterocolitis can be applied varies between pathologists (Schumacher et al. 2000). To our knowledge there are no 'reference values' for the number of eosinophils in histological sections of the gastro-intestinal tract in clinically healthy horses, and there may be a misleadingly high prevalence of intestinal eosinophilic infiltration in clinically healthy horses as a normal resident leukocyte population. The objective of this study was to evaluate the extent of eosinophilic infiltration in rectal biopsies from clinically healthy horses and to establish the repeatability of these findings.

\section{Materials and Methods}

Seven clinically healthy adult Dutch Warmblood horses owned by the university clinic, dewormed regularly and fed with concentrate and hay were subjected to two standard rectal biopsy procedures on Day-1 and on Day- 15 to compare the results between samples taken on the same day from different sites and samples taken after a 14-day interval.

The horses were restrained in stocks for the procedure. Biopsy specimens using a standard uterine biopsy instrument were collected at 10:00 and 2:00 o'clock $30-35 \mathrm{~cm}$ proximal to the anal sphincter (Figure 1).

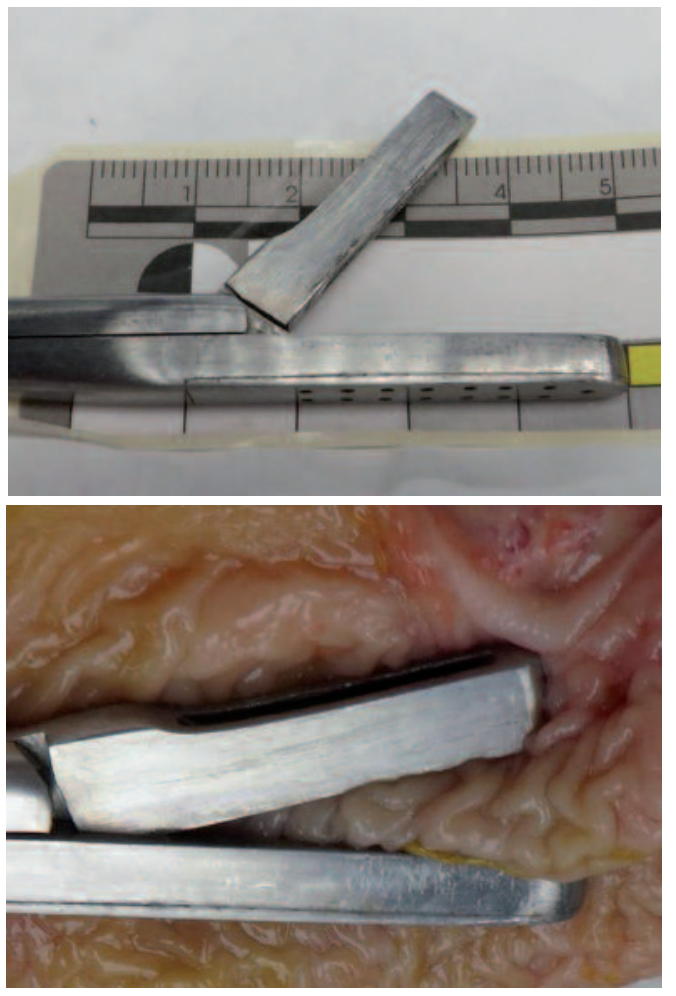

Fig. 1a and b Uterus biopsy instrument 
After fixation in 10\% phosphate buffered formalin biopsies were processed using paraffin wax. Sections $(5 \mu \mathrm{m})$ were stained with haematoxylin and eosin and quantitatively evaluated for eosinophilic infiltration by counting the eosinophils in the lamina propria mucosae and in the submucosa in the full length of the biopsy both, and counting the number of crypts too. In this way it was possible to estimate the mean number of eosinophils per crypt area (Figures 2-5).

IBM SPPS 22 computer software was used for statistical evaluation.

\section{Results}

The procedure of taking rectal biopsies seemed a relatively safe and painless procedure for the horse if it stands in stocks

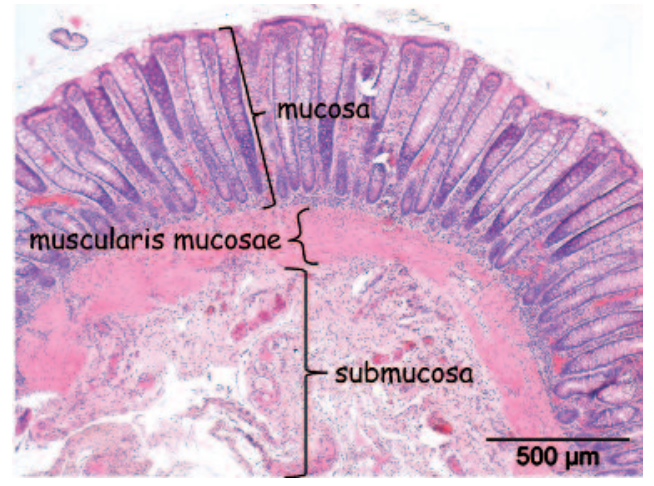

Fig. 2 Biopsy of the rectum, mucosa, muscularis mucosae and submucosa are indicated.

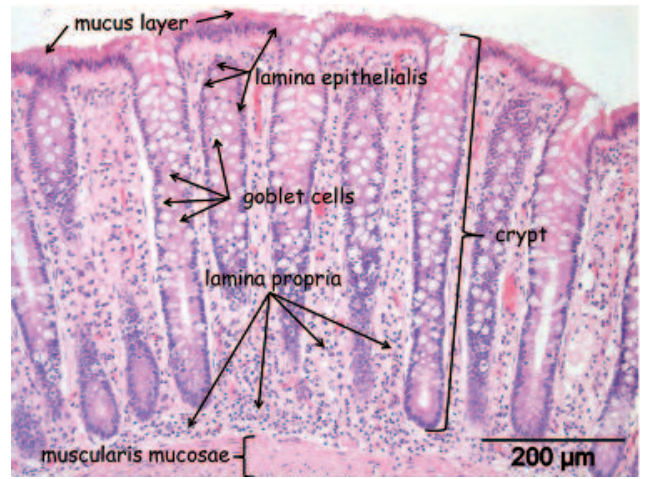

Fig. 3 Biopsy of the rectum showing details of the mucosa. and is restrained properly. None of the horses showed any signs of discomfort during or after the procedure.

In three of the seven horses all four biopsies were of sufficient quality to be evaluated. In three horses one of the samples and two samples in one horse could not be evaluated because these were too small or were damaged during collection or processing (Table 1).

The mean number of crypts that could be evaluated per slide was $50 \pm 18$ (range 26-104 crypts/slide). The intra-individual correlation of the eosinophils/crypt-area ratio of the horses was only significant for the data of the lamina propria mucosae of the second sample on Day-1 and on Day-15 (0.93; $p=0.022)$

Eosinophils were consistently found in all samples to a varying extent and the numbers were considered to be high in some horses (Figure 6).

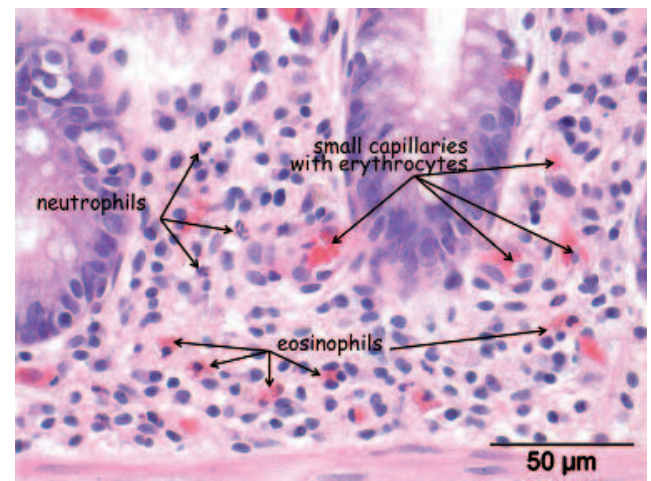

Fig. 4 Biopsy of the rectum showing further detail of the lamina propria.

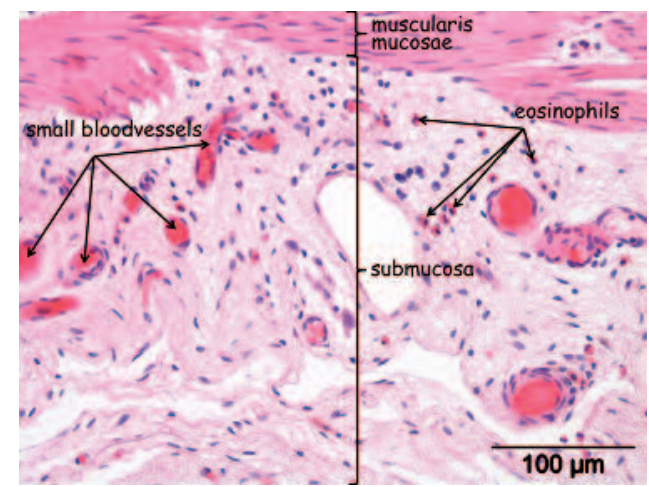

Fig. 5 Biopsy of the rectum showing details of the submucosa

Table 1 Mean number of eosinophils per crypt area in the rectal biopsies of 7 healthy horses; green = all four biopsies were evaluated both in the lamina propria and in the submucosa, blue $=3$ biopsies were evaluated both in the lamina propria and in the submucosa and orange $=2$ biopsies were evaluated both in the lamina propria and in the submucosa.

\begin{tabular}{|c|c|c|c|c|c|c|c|c|}
\hline \multirow[b]{2}{*}{ horse } & \multicolumn{4}{|c|}{ lamina propria } & \multicolumn{4}{|c|}{ submucosa } \\
\hline & sl & s2 & s3 & s4 & sl & s2 & s3 & s4 \\
\hline 1 & 0.5 & 0.3 & 0.5 & 1.1 & 1.6 & 1.7 & 0.4 & 1.3 \\
\hline 2 & 0.8 & 0.3 & 0.8 & & 1.7 & 1.3 & 3.0 & \\
\hline 3 & 0.3 & 1.0 & 0.6 & & 2.0 & 3.9 & 0.4 & \\
\hline 4 & 0.2 & 0.5 & 0.7 & 0.7 & 1.6 & 1.2 & 0.3 & \\
\hline 5 & 1.1 & 0.8 & 2.2 & 1.4 & 0.8 & 1.2 & 0.7 & 0.5 \\
\hline 6 & & 1.8 & 1.1 & 2.7 & & 0.8 & 3.4 & \\
\hline 7 & 0.7 & 0.4 & 0.8 & 0.4 & 1.9 & 1.6 & 0.6 & 9.9 \\
\hline
\end{tabular}


Repeated rectal biopsies in 7 clinically healthy horses

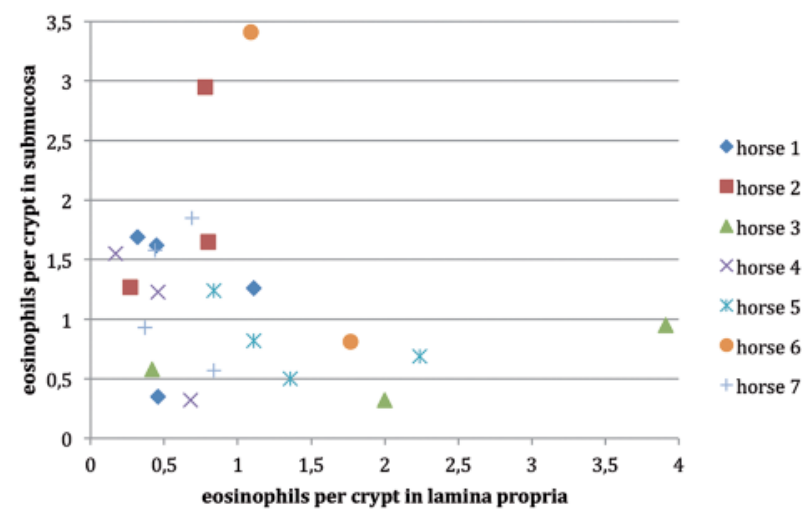

Fig. 6 Variation in number of eosinophils per crypt area in the lamina propria and in the submucosa in different rectal biopsy samples of seven horses.

\section{Discussion}

The fact that none of the horses used in the present study showed any signs of discomfort during or after the biopsy procedure may be related to the fact that all horses were experienced teaching horses, completely used to rectal palpation and thus very relaxed during the procedure. As the horses were not euthanized after the procedure there is no further macroscopic or microscopic information of lesions resulting from the biopsy procedure. Ricketts (1996) described rectal biopsy also as a safe procedure. In the study of Laroux et al. (2011) $44 \%$ of the biopsies showed hematomas after rectal biopsy. These authors, however, took biopsies of the rectum at 15 and $30 \mathrm{~cm}$ from the anal sphincter at 10:00, 02:00, 04:00 and 08:00 $\mathrm{h}$ just before euthanasia of the horses, and they mentioned that most of the hematomas were found at the ventral biopsy sites. In the present study biopsies were only taken at 10:00 and 02:00 h.

Although all biopsies were taken by an in this procedure experienced clinician 5 of the 28 biopsies (18\%) could not be evaluated as these were too small or too much damaged. This problem is not mentioned in publications that described the procedure (Leroux et al. 2011 , Taylor 2002), but it indicates that in an equine patient at least two biopsies should be taken.

Earlier studies identified specific inflammatory cell types in rectal biopsies semi-quantitatively as a percentage of the total cell infiltrate (Mäkinen et al. 2008). In the present study the mean eosinophil count per crypt area was used to provide an objective assessment of the eosinophilic infiltration. To our knowledge this has not been described earlier.

The marked regional and temporal variation in the number of eosinophils in both the rectal mucosa (lamina propria) and submucosa of clinically healthy horses has been mentioned earlier by Mair et al. (2006) although this was not supported with data.

In conclusion: the large variation in number of eosinophils in the rectal mucosa and submucosa in clinically healthy horses and the relatively small size of rectal biopsies compared to the total length of the equine large bowel, may decrease the sensitivity of rectal biopsies in establishing the diagnosis of inflammatory bowel disease.

\section{Acknowledgement}

The authors thank prof. Lutz Goehring, DVM, PhD and Angelique Jongbloets, DVM for help in obtaining the samples, Ted van den Ingh, DVM, PhD for histological evaluation and prof. Derek Knottenbelt, DVM, PhD for his help to prepare the manuscript.

\section{Animal Welfare Statement}

The study was approved by the Utrecht Animal Ethical Committee. Reference number DEC 0102.0518.

\section{References}

Leroux A., Cassart D., Amory H., van Galen G. (2011) Rectal biopsies in 12 horses: technique, safety and diagnostic value of histopathology. Abstracts of the 4th Congress of the European College of Equine Internal Medicine, 4-5 Feb 2011 Hannover, published in J. Vet. Intern. Med. 25, 624

Lindberg R., Nygren A., Persson S. G. B. (1996) Rectal biopsy diagnosis in horses with clinical signs of intestinal disorders: a retrospective study of 116 cases. Equine Vet. J. 28, 275-284

Mair T. S. Pearson G. R., Divers T. J. (2006) Malabsorption syndromes in the horse. Equine Vet. Educ. 18, 299-308

Mäkinen P. E., Archer D. C., Baptiste K. E., Malbon A., Proudman C. J., Kipar A. (2008) Characterisation of the inflammatory reaction in equine idiopathic focal eosinophilic enteritis and diffuse eosinophilic enteritis. Equine Vet. J. 40, 386-392

Pass D. A., Bolton J. R. (1982) Chronic eosinophilic gastroenteritis in the horse. Vet. Pathol. 19, 486-496

Ricketts S. W. (1996) Rectal biopsy - a piece of the diagnostic jigsaw puzzle. Equine. Vet. J. 28, 254-255

Schumacher J., Edwards J. F, Cohen N. D. (2000) Chronic idiopathic inflammatory bowel diseases of the horse. J. Vet. Intern. Med. $14,258-265$

Taylor F. (2002) Rectal biopsy. Pages 9-10 in Manual of equine gasteroenterology. 1st ed. T. Mair, T. Divers and N. Ducharme eds. W.B. Saunders, London

\section{Zusammenfassung}

\section{Variabilität der eosinophilen Infiltration innerhalb der Rektalmukosa klinisch gesunder Pferde}

Die entzündliche Darmerkrankung stellt ein komplexes Syndrom dar, welches die multisystemische eosinophile epitheliotrope Erkrankung(MEED) und die idiopathische eosinophile Enterokolitis einschließt. Für die Diagnose intestinaler Erkrankungen wird oft auf die rektale Biopsie zurückgegriffen, allerdings mit unterschiedlichem Erfolg. In Fällen einer eosinophilen Gastroenteritis werden oft mikroskopische Veränderungen mit einer eosinophilen Infiltration in der Lamina propria und Submukosa beschrieben, doch werden eosinophile Granulozyten auch bei Pferden ohne eine entsprechende klinische Symptomatik diagnostiziert und somit bedeutet die Erhebung dieses Befundes nicht automatisch das Vorliegen einer MEED 
oder idiopathischen eosinophilen Enterokolitis. Nach kenntnis der Autoren gibt es für die Zahl der Eosinophilen in histologischen Schnitten des Gastrointestinaltrakts gesunder Pferde keine Referenzwerte und eine Unterscheidung zwischen vermehrter eosinophiler Infiltration und normaler Leukozytenpobulation kann schwierig sein. Ziel der Untersuchung war es, das Ausmaß der eosinophilen Infiltration in Biopsieproben der Rektumschleimhaut klinisch gesunder Pferde zu erheben und die Reproduzierbarkeit dieser Befunde zu bestätigen.

Bei 7 klinisch regelmäßig entwurmten Warmblütern, die mi† Kraftfutter und Heu gefüttert waren, wurden an zwei Tagen im Abstand von 2 Wochen Biopsieproben entnommen. Dafür wurden die Pferde in einen Zwangstand gebracht und mit einer Uterusbiopsiezange an Position 10 Uhr und 14 Uhr ca. $30-35 \mathrm{~cm}$ proximal des Anus Proben genommen. Diese wurde in Formalin fixiert und in Paraffin eingebettet. Die Schnitte $(5 \mu \mathrm{m})$ wurden mit Haematoxylin und Eosin gefärbt und die eosinophile Infiltration quantitativ durch Zählung der Zellen in der Lamina propria mucosae sowie in der Submukosa auf der gesamten Probenlänge und innerhalb der Krypten erfasst. Bei 3 Proben konnte keine Auswertung erfolgen, da die Proben zu klein waren oder während der Behandlung beschädigt worden waren. In allen Schnitten fanden sich eosinophile Granulozyten in unterschiedlichem Ausmaß und in Abhängigkeit vom Pferd. Bei einigen Tieren erschien diese Anzahl sehr hoch. So variierte die durchschnittliche Anzahl der Eosinophilen pro Krypte in der Lamina propria bei den vier unterschiedlichen Proben bei einem Pferd zwischen 0,2 und 0,7 und bei einem anderen Tier zwischen 0,8 und 2,2. In der Submukosa lag eine ähnliche Variation vor, wobei die durchschnittliche Anzahl bei zwei Proben bei einem Pferd 0,4 bzw. 0,7 und bei einem anderen Tier 0,6 bzw. 9,9 betrug. Die Tatsache, dass keine der in der Studie verwendeten Pferde während oder nach der Probeentnahme Zeichen vom Schmerz oder Unwohlsein aufwies, mag darauf zurückzuführen sein, dass alle Tiere erfahrene Lehrpferde waren, die an die rektale Untersuchung gewöhnt und so während der Biopsie völlig entspannt waren.

Da die Tiere nach der Probeentnahme nicht euthanasiert wurden, liegen keine weiteren mikro- oder makroskopischen Informationen über mögliche Folgen der Biopsie vor. Auch andere Autoren beschreiben die Rektalbiopsie als sichere Methode. In einem Fall wurde in knapp der Hälfte der Fälle von Hämatomen an der Entnahmestelle berichtet, wobei die Tiere hier kurz nach der Biopsie euthansiert worden waren. Obwohl in der aktuellen Studie alle Biopsien durch erfahrene Kliniker vorgenommen wurden, waren 5 von 28 Bioptaten entweder zu klein oder zu beschädigt, um histologische ausgewertet werden zu können. Diese Tatsache war zuvor nicht beschrieben und sie weist darauf hin, dass beim Pferdepatienten mindesten zwei Proben entnommen werden sollten. Frühere Studien identifizierten spezifische entzündliche Zelltypen in Rektalbiopsien semiquantitativ als Prozentanteil des Gesamtzellinfiltrats. In der aktuellen wurde, um eine objektivere Messung der Eosinophileninfiltration zu erreichen, für die Beurteilung die durchschnittliche Eosinophilenzahl pro Darmkrypte herangezogen. Dieses Vorgehen ist bisher nicht veröffentlicht.

Die große Variation der Anzahl der Eosinophilen in der rektalen Mukosa und Submukosa (Lamina propria) klinisch gesunder Pferde und die relativ kleine Größe der Biopsieprobe im Verhältnis zur Gesamtlänge des Dickdarms des Pferdes verringert allerdings die Sensitivität der rektalen Biopsie für die Diagnosestellung einer entzündliche Darmerkrankung. 